\title{
Hrvatska recepcija enciklike Fides et ratio
}

\author{
Ivan Šestak*
}

\begin{abstract}
Sažetak
Prilog iznosi na vidjelo prisutnost enciklike Fides et ratio Ivana Pavla II. u nas, $i$ to povodom njezine dvadesete obljetnice izlaska. S tim ciljem kronološki pokazuje osvrte na nju u našoj znanstvenoj periodici, koja se mahom vezuje uz filozofsko-teološke institucije na našem nacionalnom korpusu. Članci su većinom izlazili u časopisima Crkva u svijetu, Obnovljeni Život, Vrhbosniensia i Bogoslovska smotra, a gotovo zanemarivo na drugim mjestima. Napisi su bili prigodničarskoga karaktera, tj. izlazili su povodom objave enciklike i obilježavanja njezinih godišnjica. Riječ je o veoma dobrim prikazima čitavoga dokumenta, odnosno pojedinih njegovih dijelova u kojima je riječ o problematici kojom se autori inače bave u svojem znanstvenom radu. Oni su slijedeći okružnicu pisali o povijesno bremenitom odnosu razuma $i$ vjere, odnosno filozofije i teologije kao znanosti o vjeri, o načelnoj otvorenosti ljudskoga duha prema istini koja je i transcendentnoga karaktera, o nužnosti filozofije za teologiju, o prirodnim znanostima $i$ enciklici, o grozoti nihilizma koji predstavlja pravu negaciju ljudskosti te o ponudi poruke Isusa Krista koju je filozofiji pružio Ivan Pavao II. Valja spomenuti da su se pojedini autori znali i kritički osvrnuti na neke dijelove enciklike.
\end{abstract}

Ključne riječi: Fides et ratio, vjera, razum, filozofija, teologija

\section{Uvod}

Enciklika Fides et ratio objavljena je 14. rujna 1998. godine u Vatikanu. Bila je to trinaesta po redu od ukupno četrnaest enciklika, koliko ih je u svojem dvadesetšestogodišnjem pontifikatu potpisao sv. Ivan Pavao II. Ta je enciklika predstavljena uoči 20. obljetnice njegove papinske službe. Njezin sadržaj, uz uvod i zaključak, obuhvaća sedam poglavlja, u kojima se, među ostalima, nalazi prikaz duge, složene i bremenite problematike odnosa vjere i razuma, koji međutim želi

* Izv. prof. dr. sc. Ivan Šestak, Fakultet filozofije i religijskih znanosti Sveučilišta u Zagrebu, Jordanovac 110, 10000 Zagreb. E-adresa: isestak@ffrz.hr Ovaj je rad izmijenjeno i dopunjeno predavanje koje je održano u Zagrebu 2. listopada 2018. na međunarodnom znanstvenom skupu Fides et tratio - Vjera i razum: 20 godina poslije povodom 20. obljetnice enciklike pape Ivana Pavla II. Fides et ratio. Znanstveni skup organizirali su: Fakultet filozofije i religijskih znanosti Sveučilišta u Zagrebu, Institut sv. Tome Akvinskoga, Filozofski fakultet Papinskoga sveučilišta sv. Tome Akvinskoga u Rimu (Angelicum), Zagreb, 2. listopada 2018. 
dati i smjerokaz tomu odnosu u novom tisućljeću. Riječ je ujedno i o prvoj enciklici koja je nakon glasovite Aeterni Patris Lava XIII. iz godine 1879. progovorila o filozofiji, osobito o njezinu odnosu prema teologiji kao znanosti o vjeri.

O recepciji enciklike Fides et ratio općenito današnji se komentatori uglavnom slažu da je ona već na samom izlasku naišla na suzdržan prijem. Javnost je Ivan Pavla II. percipirala karizmatikom i mistikom s velikim političkim vizijama, a manje intelektualnom figurom, premda je i on sam bio profesor filozofije personalističke usmjerbe na Katoličkom sveučilištu u Lublinu. Da je, kako neki smatraju, encikliku kojim slučajem potpisao, a ne samo predstavio, kardinal Josef Ratzinger kao tadašnji prefekt Kongregacije za nauk vjere, bilo bi to drugačije. Njega su naime mnogi filozofi, naravno i ateistički, respektirali kao oštroumnoga mislioca. Je li, i u kojoj mjeri, Ratzinger na enciklici radio, ostaje naravno tajna. No, unutar vatikanskih zidova moglo se čuti da je encikliku trebalo nazvati »Fisichella et Ratzinger « (Ring-Eifel, 2018). Rino Fisichella bio je ugledni profesor fundamentalne teologije, među ostalim i na Papinskom sveučilištu Gregoriana, koji je encikliku i predstavio podužim uvodom za glasovito talijansko izdanje Edizioni Piemme (Fisichela, 1998, 9-43). U svakom slučaju, profesor Fisichela ubrzo je nakon izlaska enciklike bio imenovan biskupom. Izvrsnu podlogu za recepciju enciklike na engleskom jeziku načinio je vatikanski Osservatore Romano u svojem tjednom izdanju za SAD, koji je u 17 priloga najeminentnijih filozofa, odnosno teologa, pod zajedničkim naslovom Reflections on the Holy Father's Encyclical Fides et Ratio od 4. studenoga 1998. pa do 29. rujna 1999. popratio sadržaj enciklike (Eternal Word Television Network, s. a.).

Kakva je bila recepcija enciklike drugdje? Prema svjedočanstvu Ante Ančića, primjerice profesori filozofije u Njemačkoj, dakle u zemlji filozofije, encikliku $\mathrm{Fi}$ des et ratio jedva poznaju (Ančić, 2008, 753). Nju je doduše vrlo brzo nakon izlaska u Njemačkoj predstavio profesor dogmatike Leo Scheffczyk (1920.-2005.), koji je kasnije imenovan i kardinalom (Scheffczyk, 1999).

Kakva je njezina recepcija u nas? Ona se njezinim pojavkom, ali i obilježavanjem njezinih godišnjica, zbivala mahom na filozofsko-teološkim učilištima našega nacionalnoga korpusa, te je najvećim dijelom sasvim razumljivo ostala zabilježena i na stranicama njihovih časopisa. Na encikliku su se osvrnuli i mislioci koji nisu, odnosno nisu bili, nastavnici na crkvenim učilištima, a što je veoma vrijedan podatak. Pođimo najbolje kronološkim redom konzultirajući našu filozofsko-teološku periodiku.

\section{1. Časopis Crkva u svijetu}

Katolički bogoslovni fakultet Sveučilišta u Splitu nije doduše organizirao zasebni skup o enciklici Fides et ratio, ali je ona bila promptno predstavljena čitateljstvu već u četvrtom broju u 1998. godini u časopisu Fakulteta Crkva u svijetu. Učinio je to Ante Mateljan s dva priloga, najprije u uvodniku spomenutoga broja, gdje je na tragu enciklike pledirao za utemeljenjem razuma u Objavi (expressis verbis) »u osobi Isusa Krista kao Logosa « te — posve na tragu tradicije — za razumskim utemeljenjem vjere (Mateljan, 1998a). Isti je autor potom u jednom dužem prilogu iznio prikaz svih sedam poglavlja same enciklike (Mateljan, 1998b). 


\section{2. Časopis Obnovljeni Život}

Recepciji enciklike Fides et ratio bitno je u nas pridonio znanstveni skup koji je 16. svibnja 1999. bio upriličen na Filozofskom fakultetu Družbe Isusove u Zagrebu, a organizirali su ga spomenuti fakultet (od 2016. Fakultet filozofije i religijskih znanosti Sveučilišta u Zagrebu) i sekcija Kršćanska filozofija Hrvatskoga filozofskoga društva. Relatori su, osim nastavnika sa spomenutoga učilišta, bili i nastavnici s filozofskih, odnosno teoloških visokih učilišta iz Splita, Zadra, Đakova i Rijeke. Prilozi s toga skupa, osim jednoga, tiskani su u časopisu Obnovljeni Život, točnije u prvom i trećem broju za 2000. godinu. Tadašnji urednik napisao je uvodnik u prvom broju za 2000. godinu govoreći o značenju filozofije općenito, a potom također o njezinu odnosu prema teologiji, imajući u vidu pojavak enciklike Fides et ratio (Šestak, 2000, 3-5). U nastavku, zbog ograničenja prostora, donosimo tek glavne misli iz pojedinih priloga.

Ivan Macan (1939.-2015.) u svojem je članku naslova Što nam poručuje enciklika 'Fides et ratio'?, a koji je on dovršio vrlo brzo nakon znanstvenoga skupa, tako da je prilog bio tiskan već u prvom broju za 1999. godinu, iznio prikaz enciklike po poglavljima. Njegov sukus sastoji se u tom da razum i vjera ne moraju dovoditi do međusobnoga ukidanja, nego se naprotiv moraju uzajamno nadopunjavati i obogaćivati (Macan, 1999, 93). Autor je na kraju svojega priloga iznio i kratki osvrt na encikliku, ukazujući poglavito na Papinu veliku otvorenost prema različitosti filozofskih mišljenja i kultura (Macan, 1999, 108), što nije uvijek bio slučaj u povijesti Katoličke crkve. Treba se samo nakratko prisjetiti svih onih događanja oko dokumenta Syllabus errorum, koji je godine 1864. objavio Papa Pio IX. Macan je također zamijetio da je sv. Otac želio pridati veliko značenje studiju filozofije na crkvenim učilištima: nepoznavanje filozofije naime vodi do nepotrebnoga i suvišnoga skripticizma te opasnoga fideizma. No, Macanu je osobito drago što je enciklika prihvatila naziv »kršćanska filozofija « — naziv koji je on već zastupao na drugim mjestima — pa je istaknuo:

Ne samo što svako filozofiranje nužno započinje refleksijom nad nekim svjetonazorima (bili oni izraženi i u obliku pitanja), kršćanska je filozofija opravdana i zbog toga što bi mnoga (pa i protukršćanska) filozofska mišljenja bila drukčija da se nisu susrela ili suočila sa zasadama kršćanske vjere i objave (Macan, 1999, 109).

Izvrstan okvirni tekst za razumijevanje enciklike pružio je profesor Macan člankom Filozofija u crkvenim dokumentima, koji je objavljen godinu dana kasnije s ostalim prilozima sa spomenutoga skupa o enciklici. Riječ je o sržnoj analizi čitave panorame crkvenih dokumenata koji su počeli govoriti o filozofiji, i to od druge polovice 19. stoljeća sve do Naputka o nastavi filozofije, koji je izdala Kongregacija za katolički odgoj 1972. godine, a koji osobito vrijedi za formaciju budućih svećenika, gdje se naravno preporučuje filozofija Tome Akvinskoga (Macan, 2000, 25-37).

Niz članaka o enciklici u časopisu nastavlja se prilogom Ante Mišića naslova Otački vidici odnosa 'vjere i razuma', u kojem autor iznosi stavove crkvenih otaca i ranokršćanskih pisaca koji se u enciklici spominju (Justin, Irenej, Klement Aleksandrijski, Augustin i dr.), a ostat će primjer suzvučja vjere i razuma, odnosno teologije i filozofije, i koje je sv. Otac istaknuo kao primjer svima onima »koji nastoje svoju vjeru i razumski opravdati i izgraditi intimni odnos između teološke i filozofske mudrosti« (Mišić, 2000, 60). Mišić također zamjećuje da je čitava 
enciklika zapravo na tragu Justina, koji je neobično cijenio filozofiju nazivajući ju pravim darom koji čovjeka može približiti Bogu, a o čemu svjedoče i Augustinove riječi iz djela Contra academicos: »Nam ipsum verum non videbis, nisi in philosophiam totus intraveris« (Mišić, 2000, 58).

Nikola Stanković u svojem prilogu 'Fides et ratio' - konsekvencije za filozofiju o $B o g u$ ističe važnost insistiranja enciklike na načelnoj otvorenosti i svrhovitoj usmjerenosti ljudske spoznaje prema transcendentnoj zbilji. Kako bi se pak ta otvorenost držala budnom, autor svraća pozornost na nužnost njegovanja „implicitne filozofije", njezinih načela, koja vrijede na području postojanja, mišljenja i djelovanja.

To su ona načela po kojima se čovjek u svom mišljenju ravna i prije svake refleksije, tj. prema njima misli, a Enciklika navodi primjer: princip nekontradicije, finaliteta, kauzaliteta kao i shvaćanje osobe kao slobodnog i razumnog subjekta i njezine sposobnosti spoznati Boga, istinu i dobro. Misli se također i na temeljne moralne zakone koji su 'općenito rasprostranjeni' (Stanković, 2000, 65).

Autor doduše ističe kako enciklika sokoli čovjeka da ne izgubi povjerenje u razumske sposobnosti kadre prodrijeti do transcendentne zbilje, ali isto tako iskazuje negodovanje što enciklika nije određenija u formuliranju polazišta za ukazivanje na transcendentnu zbilju. Autoru se čini da enciklika zapravo premalo govori o onom klasičnom polazištu iz prirode (ex mundo), spominjući ga tek nakratko u br. 19. (Stanković, 2000, 68). S druge strane, autor uviđa da enciklika jako puno govori o čovjekovoj unutarnjoj žudnji za spoznajom istine, žudnji za Bogom, a što bi možda moglo biti drugo polazište za konstrukciju filozofije o Bogu: »Valjalo bi ga istražiti, osloboditi ga od subjektivnosti te na osnovi toga stvoriti općevaljane zaključke« (Stanković, 2000, 68). Na kraju autor na tragu enciklike, koja ističe otvorenost ljudske naravi prema nadzbilji, čini pledoaje, nagovor za polazišta za spekulativnu konstrukciju o transcendentnoj zbilji:

»Zadaća je današnjih filozofa pronaći najprikladnija polazišta u razgovoru s kulturama, civilizacijama, umjetnosti, znanosti, mudrošću i filozofijom, cjelokupnim ljudskim obzorom te pronaći ukaze na transcendenciju, a zatim ukorijeniti sve iskustvo u zadnjem temelju sve zbilje kao i iskustva određena tom istom zbiljom «(Stanković, 2000, 69).

Ivan Zelić u svojem članku naslova Toma Akvinski u Enciklici 'Fides et ratio' ustvrđuje da Anđeoskomu Naučitelju u kršćanskoj misli, kao uostalom i u samoj enciklici, nesumnjivo pripada locus omnino singularis, pa se u tom duhu i nabrajaju njegove velike zasluge — baš kao i zasluge nekih njegovih najsuvremenijih sljedbenika, primjerice Maritaina i Gilsona - ali se on, baš kao ni neotomizam, ipak ne stavlja u neki isključiv položaj unutar sveukupne ljudske misli, uzimajući u obzir br. 51 enciklike: »Nijedan povijesni oblik filozofije, papa to izričito kaže, ne može imati pretenziju da je iscrpio svu istinu, niti da je do kraja objasnio svijet, čovjeka i njegov odnos prema Bogu « (Zelić, 2000, 76). Dapače, i sam se je tomizam morao otvarati u budućnosti novim poticajima ako želi biti plodonosan. On je to također i učinio. U tom duhu — da naime nijedan povijesni oblik filozofije ne može imati pretenziju da je iscrpio svu istinu — spominje enciklika i pravoslavne ruske kršćanske filozofe, čija je misao — sklonija viziji i sintezi drugačija od naše zapadne, a što »hoće reći da je i takav put bogat, prihvatljiv i vodi k Bogu «, kako to u svojem prilogu naslova Uloga i odnos vjere i uma u ruskoj religijskoj filozofiji piše đakovački profesor filozofije Slavko Platz (2000, 81-90). 
U članku se navode Čaadajev, Solovjev, Florenskij i Losskij te se ukratko izlaže njihovo shvaćanje odnosa razuma i vjere.

'Veritatis splendor' $i$ 'Fides et ratio' — dva krila jednog triptiha naslov je članka riječkoga nadbiskupa mons. Ivana Devčića, koji, kao i ostali komentatori, vidi da je Fides et ratio nastavak enciklike Veritatis splendor. »U enciklici Fides et ratio riječ je o krizi spoznaje, a u Veritatis splendor o krizi morala. Vidi se također da se te dvije krize međusobno uvjetuju i upućuju na krizu samog čovjeka« (Devčić, 2000, 92). Naime, iz krize istine - ako se ona drži suženom samo na svoje granice, na puku spoznaju svijeta i društva, a zatvorenom prema metafizičkoj zbilji — rađa se kriza morala, koja slobodu i savjest emancipira od svake heteronomije, i koja kao takva napokon rađa religioznom krizom koja označuje soteriološku krizu: odbacivanje Krista, Svjetla istine i Otkupitelja čovjeka. Takav slijed prema Devčiću ne može ne imati kobne posljedice na društvenom području: »Stoga, nijekanje takvih normi povlači za sobom duboku društvenu krizu, rađa totalitarizam, anarhizam, različita društvena zla i nepravde « (Devčić, 2000, 97). Ivan Pavao II., kao što je poznato, nije ostao samo na dijagnozi stanja, nego je ponudio i „terapiju”: on se ne libi ukazati filozofima, odnosno modernomu čovjeku na mogućnost da se kriza nadiđe prihvaćanjem Objave. Papa zapravo drži da su vjera i razum jedna spoznajna moć: »Treba radije govoriti o jednoj moći s dva aspekta ili krila. Kao što čovjek s jednim plućnim krilom može životariti, a tek s oba istinski živjeti, tako mu je moguće s jednim krilom svoje spoznajne moći dosegnuti samo fragmente $\mathrm{i}$ krhotine one istine koju u punini otkriva ako joj leti u susret na oba krila« (Devčić, 2000, 99). Istini se dakle leti i razumom i vjerom!

Borislav Dadić, profesor filozofije na Sveučilištu u Zadru, nastupio je na skupu s predavanjem Metafizika u enciklici Fides et ratio te je i njegov članak objavljen u časopisu Obnovljeni Život. Autor je istaknuo da ta enciklika zapravo predstavlja istinski pledoaje za metafiziku, odnosno za filozofiju općenito, i to u jednom za njih potpuno oskudnom vremenu (dürftige Zeit!). Covjek svojom težnjom prema znanju, odnosno istini, pokazuje da je biće koje je otvoreno za transcendentnu zbilju. U svojoj težnji za znanjem, odnosno istinom, čovjek naime traži primjeren odgovor i na ona sveobuhvatna pitanja koja se tiču pitanja smisla života i smrti.

Upravo u tom traganju za onom 'zadnjom istinom koja može objasniti smisao života', najbolje se očituje metafizička narav toga istraživanja. Ta posljednja stvarnost prema kojoj teži naš um jest onaj prvi princip svega postojećeg, a kojega metafizika naziva aktom bivstvovanja (actus essendi), a njegovu spoznaju smatra najvišim dosegom naravnih sposobnosti ljudskoga uma (Dadić, 2000, 390-391).

Tu je riječ općenito o metafizičkoj spoznaji koja je u metafizici Tome Akvinskoga dosegnula svoj vrhunac temeljeći se na aktu bivstvovanja (actus essendi) kao svojem prvom načelu, a koji je potom bio plodonosan i za teološke discipline. Tako enciklika poziva filozofe na povjerenje u ljudski razum, na metafiziku, točnije na metafiziku bitka, o kojoj autor, referirajući se na br. 76. enciklike kaže: »Upravo $\mathrm{u}$ horizontu ovakve metafizike nastaje i razvija se pojam o osobnom Bogu kao slobodnom Stvoritelju svijeta i o osobi kao duhovnom biću« (Dadić, 2000, 395). Enciklika pak u osobi vidi privilegirano mjesto za polazište takve metafizike.

I Ivan Tadić, profesor filozofije na Katoličkom bogoslovnom fakulteta Sveučilišta u Splitu, u svojem je veoma opširnom i dokumentiranom članku naslova Razum i spoznaja u enciklici Fides et ratio prepoznao u okružnici poziv filozofima 
na povjerenje u ljudski razum, na metafiziku, točnije na metafiziku bitka koja je sposobna nadići osjetilnu zbilju te spoznati izvor svega, Stvoritelja! Papinu ponudu kršćanske objave u osobi Isusa Krista kao logosa filozofima o pitanju smisla ljudskoga život autor naziva »kristocentrični egzistencijalizam« (Tadić, 2000, 39).

Na skupu je nastupio i Rudolf Brajičić (1918.-2007.) svojim predavanjem Proširenje filozofije na područje Objave, kojim se, čini se, želio usprotiviti tendenciji moderne teologije, koja je sa svojih katedri nastojala otjerati svaku spekulaciju, odnosno filozofiju! Zašto Brajičić želi proširiti filozofiju na područje Objave? On je i kao izvrstan filozof stvar samo domislio do kraja: filozofija se po svojoj vokaciji ne smije zatvoriti nijednom isječku zbilje, pa zato i sadržaj Objave može biti materijalni objekt proučavanja filozofije! To proširenje filozofije na teologiju s namjerom da se objavljeni sadržaj znanstveno obrazloži do posljednjih uzroka naziva Brajičić »integralna kršćanska filozofija«. »Pod tim vidikom filozof ne posuđuje Objavi svoj filozofski instrumentarij i ostalo što joj je potrebno da bude znanost, nego, da se slikovito izrazim, Objava filozofu otvara svoje obale da se iskrca na njezino područje i da se na njemu filozofski zaposli« (Brajičić, 2000, 101). No, ne predstavlja li ta integralna kršćanska filozofija, odnosno spekulativna teologija, zbog svoje deducirajuće racionalizacije, zapravo skandal za Božju riječ, zar ona ne nagrđuje objavljeni sadržaj, zar uopće treba spekulativno razlagati misterij, a što je na liniji načela i nemoguće? Brajičić je uvjeren »da se tek primjenom filozofske refleksije na misterij, on rascvjetava. Sjetimo se Trojstva, u kojem filozofiranjem nailazimo na izlaženja, pa na relacije, zatim na specifične osobnosti u tom misteriju « (Brajičić, 2000, 103). U svakom slučaju, tim se prilogom Brajičić samo pridružio zahtjevu okružnice da filozofiju valja više cijeniti na crkvenim učilištima.

\section{3. Časopis Vrhbosniensia}

Nešto više od godinu dana nakon pojavka enciklike Fides et ratio, točnije 23. listopada 1999., tadašnja Vrhbosanska katolička teologija u Sarajevu (od godine 2013. pod nazivom Katolički bogoslovni fakultet u sklopu Univerziteta u Sarajevu) organizirala je okrugli stol o enciklici Fides et ratio, a njegovi su prilozi objavljeni iste godine u drugom broju časopisa Vrbosniensia. Encikliku je svojim prilogom naslova Okolnosti $i$ sadržaj enciklike Fides et ratio uvodno predstavio profesor Tomislav Jozić, iznijevši njezin okvirni sadržaj. Taj se prikaz u bitnom ne razlikuje od ostalih sličnih prikaza spomenutih u ovom prilogu, ali ipak valja istaknuti i jedan detalj koji kod drugih autora ne nalazimo, a to je kontekst njezina nastanka: »Nije bez razloga ova enciklika nastala baš u naše vrijeme, jer je ono doseglo vrh nepovjerenja, sumnji i očaja spram ljudskog razuma i antropologije uopće (kriminal, ratovi, ljudska prava, kulturalni antagonizmi, ekologija i slično)«(Jozić, 1999, 298).

Svetopisamski osvrt na encikliku načinio je bibličar profesor Mato Zovkić interventom koji je pretočio u prilog naslova Riječ Božja u enciklici Fides et ratio te ga završio riječima koje inače potvrđuju namisao enciklike da istina nije rezervirana samo za jedan filozofski sustav te da, osim toga, teološke discipline moraju ozbiljno uzeti u obzir dosege filozofije u svojem metodološkom postupku: »Bibličari mogu i trebaju uvažavati filozofsko razmišljanje upravo zato što vjeruju da je Riječ Božja upućena svim ljudima« (Zovkić, 1999, 305). 
Franjevački filozof Vili Radman imao je na okruglom stolu intervent naslova Potraga za istinom kao antropološka pretpostavka kršćanske vjere. U svojem je članku analizirao »okvir unutar kojega odnos između filozofije i teologije posebno dobiva na svojoj važnosti za kršćansku vjeru« (Radman, 1999, 306). Covjek naime žudi za istinom, i to ne tek za ovom ili onom, nego i za onom sveobuhvatnom o smislu vlastitoga života. U tom mu žuđenom traženju Objava nadolazi kao mogućnost dovršetka i smiraja te potrage. U metodološkoj artikulaciji te težnje za sveobuhvatnom istinom Papa osobito ističe važnost filozofije. No ipak ne bilo kakve filozofije, nego one koja je otvorena transcendenciji: »Ako ta dimenzija filozofskog promišljanja nestane, onda je put kojim objavljena istina mora proći do srca današnjih ljudi daleko teži. Crkva stoga s pravom drži filozofiju jednim od oruđa svoga evangelizatorskog djelovanja« (Radman, 1999, 311). Valja dakle promovirati filozofiju koja pripomaže shvaćanju kršćanske ponude istine, njezinomu tumačenju, ali i danas predstavlja gotovo jedino sredstvo komunikacije s onima koji ne dijele kršćanski svjetonazor.

Filozof Željko Pavić iz Leksikografskoga zavoda Miroslav Krleža u Zagrebu svoj je intervent na okruglom stolu u Sarajevu uobličio u obuhvatniji, dokumentirani i smjerodavni filozofski prilog koji nosi naslov Bog Abrahamov i Bog filozofa: Filozofijski dometi enciklike Fides et ratio. Smjerodavnost izranja iz otvorenosti prema drugim kulturama, filozofijama i filozofskim smjerovima, koju je u enciklici trasirao sam Ivan Pavao II. Na temelju toga Pavić daje zadaću teolozima i kršćanskim filozofima danas:

Riječju, neoskolastika ne smije previše ići svojim putem, voditi dijalog sama sa sobom, nego se obratiti svojemu vremenu i njegovim problemima, jer samo pod tom pretpostavkom vjernik će ponovno dati prinos filozofiji u njezinu osvjetljavanju zbiljnosti i smisla ljudskog života, učiniti filozofiju kršćanskom, a filozofa 'vjernikom' u smislu koji nadmašuje svaku kontingentnu vjersku podjelu. Tek tada će krilo vjere i krilo razuma uistinu moći s lakoćom nositi jedno tijelo mudrosti (Pavić, 1999, 337).

Pavić kao vrstan filozof i poznavatelj povijesti filozofije uočio je kako enciklika uviđa besmislenost i nihilizam u koji je filozofija zapala u 20. stoljeću, a potom i Papin „manevar”, koji se očitovao u evanđeoskoj ponudi istine u Kristu samoj filozofiji:

S druge strane, filozofija, koja je u ovom stoljeću najdublje iskusila 'krizu smisla', mogla bi prema Papi upravo u vjeri naći novi izvor smislenosti ljudske egzistencije $\mathrm{i}$ istodobno vratiti povjerenje u samu sebe. [...] U tom izmijenjenom odnosu teologije prema filozofiji kao filozofiji i s druge strane filozofije prema istini, koja nije nikakvo isključivo vlasništvo europske ili bilo koje druge kulture, možda bi ponovno mogao biti omogućen jedan susret u kojem bi filozofi mogli ponovno razumjeti Boga Abrahamova, Izakova i Jakovljeva, Onoga koji je najdostojniji njihova promišljanja. (Pavić, 1999, 337)

Na kraju Pavić, na temelju iskustva Izraela, koje pronalazi u enciklici, daje tri pravila koja um treba obdržavati kako bi se oslobodio vlastite hybris, tj. ohole samodostatnosti:

Prvo pravilo sastoji se u tome da se razum drži ove istine: čovjek je postavljen na put koji se ne može prekinuti; drugo se pravilo rađa iz svijesti da na taj put ne stupa nitko tko je ohola duha držeći kako je sve djelo njegovih sila; treće se pravilo sastoji 
u 'strahu Gospodnjem', čiju vrhovnu transcendenciju razum mora priznati isto kao i brižnu ljubav u upravljanju stvarima. (Pavić, 1999, 337)

Franjevac, profesor teologije Luka Markešić (1937.-2014.) u svojem je članku naslova Današnje zadaće teologije prema enciklici Fides et ratio ukazao na dvije zadaće: aggiornamento metode poučavanja, za što joj je potrebna filozofija, te drugo, da iznese razumijevanje objave i nauka vjere, gdje je riječ o činjenici objave Boga i spasenja čovjeka u Kristu (Markešić, 2000, 341).

\section{4. Časopis Bogoslovska smotra}

Katolički bogoslovni fakultet Sveučilišta u Zagrebu nije organizirao skup povodom samog izlaska enciklike Fides et ratio. U časopisu Bogoslovska smotra spomenutoga fakulteta također nije bilo osvrta na pojavak enciklike, baš kao ni u Riječkom teološkom časopisu, koji je tih godina stasao. U Bogoslovskoj smotri objavljeno je međutim nekoliko izvrsnih priloga godine 2008. povodom desete obljetnice izlaska enciklike.

Teolog Ančić s veće se vremenske udaljenosti zaustavio na nekim temama enciklike, pa i sa svojeg fundamentalno-teološkoga motrišta. Nakon prikaza enciklike daje i pregled njezine recepcije u nas i u inozemstvu, ustvrđujući da je njezin dotadašnji odjek bio zapravo neznatan. Tako se s našega prostora navodi simpozij Filozofskoga fakulteta Družbe Isusove, okrugli stol Katoličkoga bogoslovnoga fakulteta u Sarajevu te manji odjeci u inozemstvu. Zaustavljajući se pobliže na komentaru prvoga dijela enciklike s fundamentalno-teološkoga stajališta, autor upućuje na njezinu Wirkungsgeschichte, koja se dogodila kod samoga Josefa Ratzingera, odnosno Benedikta XVI., koji je tematiziranje odnosa vjere i razuma u smjeru uzajamne upućenosti i suzvučja iznesenoga u enciklici upotrijebio u svojem nastojanju promicanja dijaloga vjera i kultura. Tu se, među ostalim, citira poznata rečenica iz njegova predavanja na Sveučilištu u Regensburgu godine 2006., koja se u najnovije vrijeme sve snažnije obistinjuje, a glasi: »Um koji je gluh za božansko i koji je religiju gurnuo u područje subkulture, nije sposoban za dijalog kultura « (Ančić, 2008, 758). Kulture su naime snažno prožete religijom. Autor završava navodom iz enciklike koji poziva na dijalog i međusobno prožimanje vjere i razuma:

Razum lišen objave zalazi na stranputicu koja dovodi do opasnosti da se ne vidi krajnji cilj. Vjera bez razuma iznosi osjećaje i iskustvo te tako upada u opasnost da više ne bude sveopća ponuda. Pogrešno je misliti da je vjera pred slabim razumom moćnija; naprotiv, ona sama dospijeva u opasnost da postane bajkom ili praznovjerjem. $\mathrm{Na}$ isti način razum, pred kojim se ne nalazi čvrsta vjera, nije više izazvan promotriti novost i radikalnost samoga 'biti'. (FR 48 prema Ančić, 2008, 760)

Tadašnji profesor Katoličkoga bogoslovnoga fakulteta Tomislav Ivančić (1938.-2017.) u svojem je kraćem prilogu naslova Fides et ratio nakon deset godina među ostalim uputio na potrebu interdisciplinarnosti u teološkom studiju danas (Ivančić, 2008, 761-767).

Povodom 10. obljetnice enciklike uredništvo časopisa Bogoslovska smotra objavilo je i članak glasovitoga njemačkoga teologa, umirovljenoga profesora Sveučilišta u Heidelbergu, Petera Hünermanna (1929.) pod naslovom Fides et ratio — nekoć i sad(?!). Autor u njemu ustvrđuje da je taj odnos posljednji put bio tematiziran prije više od stotinu godina, i to u enciklici Aeterni Patris Lava XIII 
(1879.), a Ivan Pavao II. svojom ga je enciklikom nadopunio, upućujući na prožimanje vjere i mišljenja, a da pri tom nije zaboravio istaknuti razlikovanje vjere i mišljenja, kao ni zaobilaznu važnost mišljenja za vjeru. Iz toga su priloga, među ostalim, važni usmjeravajući zaključci za značenje filozofskoga studija u odnosu na onaj teološki, koje autor izvodi iz razumijevanja odnosa vjere i razuma Ivana Pavla II. Tako jedan od njih ističe nezaobilaznost filozofije za sve teološke discipline, a drugi ukazuje na nužnost filozofske izobrazbe teologa. No, Hünermann napominje sljedeće: »Ipak nije od presudne važnosti količina posredovane građe, nego naučiti teologe filozofski razmišljati da bi tako mogli primjereno izlagati i posredovati temeljne sadržaje vjere « (Hünermann, 2008, 737).

$\mathrm{U}$ istom broju časopisa Bogoslovska smotra pronalazimo izvrstan kratki prilog Branka Despota naslova Vjera i filozofija (s ovu i onu stranu uma). Autor je prilog posvetio filozofu, svojemu »netom preminulome prijatelju, u nerodivome duhu živućem Marijanu Cipri« (Despot, 2008, 746). Taj osebujni zagrebački filozof temeljni problem današnjice, koji se očito dokopao svih segmenata javnoga života i kulture te sve nagriza, vidi u nihilizmu, kojega i filozofija i teologija, i to samo one, poštujući svoje kompetencije i jedna drugu, mogu dokrajčiti:

Fides i ssitudo). Stvar je u tome da, odazivajući se svome pozivu (vocatio) i reintegrirajući svoje dostojanstvo (dignitas), budu na visini zadatka. Zadatak jest: skršiti nihilizam u njegovu bitstvu. Pri tome najveća opasnost leži u podcjenjivanju neprijatelja, kako to podcjenjivanje dolazi, uz ostalo, do izražaja u neosnovanoj samouvjerenosti koja govori o deceptio autonomiae (br. 80). Nije deceptio (prevara, 'iluzija'), nego je obično sebe-samo-obmanjivanje, ispod naivne, upravo infantilne riječi 'globalizacija', ne vidjeti samu stvar, tj. progredirajući, progresivni nihilizam, koji sebe sama autonomno proizvodi kao bezbožni, protuprirodni, nečovječni znanstveno-tehničko-kibernetički totalitet. Ondje gdje se radi o bitnome, tu nikakova kolaboracija, s takozvanim 'današnjim svijetom' ne dolazi u obzir. Bog i čovjek nahode se u nihilizmu u istoj nemogućnosti. (Despot, 2008, 745)

Je li i na koji je način ta pobjeda nad nihilizmom kao jedinim pravim neprijateljem moguća? Despot:

Filozofija, s jedne strane, kao plodonosna ljubav nerođene mudrosti, i vjera, s druge strane, kao ljubav rođena u križu i uskrsnućem preporođena, mogu možda smoći snage i odvažnosti za neodgodivi, jedino nužni, okršaj s bitstvom nihilizma. Do odluke u ovome 'mogu možda' preostaje nam učeni muk, doctum silentium. A iskrenosti, poštenju i čestitosti kako vjere tako i filozofije odgovara pri tome izvrština, virtus, koja bi da se imenuje docta taciturnitas, učena šutljivost, ili, kako bi naši stari rekli, vučena tihoća. (Despot, 2008, 745-746)

U časopisu Bogoslovska smotra objavljen je godine 2014. i jedan članak filozofa, političara i diplomata Franje Zenka (1931.-2017.) pod naslovom Razum $i$ vjera. Članak obiluje, blago rečeno, prijeporima! Tako u podnaslovu Učinci razuma na vjeru toga priloga čitamo: »Među snažnim učincima razuma na vjeru jest demokracija. Stanoviti demokratski impuls demokraciji unutar katolicizma dao je svakako papa Benedikt XVI. svojim odreknućem od papinske vlasti« (Zenko, 2014, 237). Potom malo dalje: »Opće je prihvaćena teza da univerzalno načelo demokratizma ima svoje svjetovne korijene « (Zenko, 2014, 238). Potom: »Dijalog i snošljivost prema različitim narodima i njihovim religijama daljnji je učinak 
razuma na vjeru « (Zenko, 2014, 238). I naposljetku: »Znamo kako znanje ruši mitove i u krajnjoj liniji i vjeru, sukladno Kantovoj poznatoj izreci da mora ukinuti znanje kako bi učinio mjesta vjeri« (Zenko 2014, 241). Tako se za Franju Zenka, inače nekadašnjega veleposlanika Republike Hrvatske pri Svetoj Stolici (2000.-2004.), na kraju krajeva razum i vjera niti nadopunjuju, niti suprotstavljaju, niti neposredovano žive jedno pored drugoga, nego se razum pokazuje neprijateljskim prema vjeri te ju, na kraju krajeva, dokida!

Povodom dvadesete obljetnice enciklike Katolički bogoslovni fakultet Sveučilišta u Zagrebu, Katedra fundamentalne teologije, u suorganizaciji s Papinskim lateranskim sveučilištem iz Rima i Teološkim fakultetom iz Ljubljane, organizirao je 14. rujna 2018. međunarodni znanstveni simpozij Fides et ratio - Vjera $i$ razum: Aktualizirano čitanje 20 godina poslije. Pisani rezultati se očekuju.

\section{Ostalo}

Godine 1999. filozof Nikola Skledar (1942.-2011.) člankom Vjera i um u časopisu Zaprešićki godišnjak osvrnuo se na Encikliku. U njemu on doduše priznaje korektnost iznesenoga Papina odnosa vjere i razuma s neotomističkoga stajališta, ali ipak zastupa da je »filozofija samobitan oblik ljudskog duha i kao takav neovisan o bilo kojem drugom obliku duha«. Tako je on ostao daleko i od shvaćanja filozofije kakvo je zastupala enciklika Aeterni Patris, kao i onoga koje je kao ponudu predložio u svojoj enciklici Ivan Pavao II. Tako je taj filozof s obzirom na religijsku zbilju, a u svojem se je radu dobrim dijelom bavio i religijom, ostao u racionalno "neposredovanom" odnosu. A poznato je da je sahranjen prema crkvenim obredima te je za njega služena i sveta misa zadušnica.

U zborniku povodom 75. obljetnice života Josipa Ćurića, kojega je godine 2002. uredio Anto Mišić, nalazimo članak švicarskoga filozofa Philiberta Secretana (1926.) naslova Kršćanska filozofija prema aeterni patris i fides et ratio, koji zahtijeva nesumnjivo pomno čitanje. Autor među ostalim izlučuje razlike između shvaćanja filozofije u enciklikama Aeterni Patris i Fides et ratio. Filozofija je za prvu bila poglavito apologetskoga karaktera, usmjerena na otkrivanje, usustavljenje i obranu istine. Kao takva ona je bila kršćanska filozofija koju je utjelovljivao Toma Akvinski, a bila je korisna teologiji, prirodnim znanostima, kulturi i umjetnosti te i političkoj misli (Secretan, 2002, 232). A što je pak s „kršćanskom filozofijom“ u enciklici Ivana Pavla II.? On naravno hvali grandioznu Akvinčevu sintezu, ali ukazuje i na druge velike mislioce koji su željeli održati veliku tradiciju kršćanske kulture u jedinstvu vjere i razuma. »U onoj mjeri u kojoj je kršćanska filozofija temeljno određena tim skladnim odnosom vjere i razuma, svi ti filozofski postupci tvore raznoliko tkivo jedne kršćanske filozofije koja se ne svodi isključivo na tomističku i neotomističku tradiciju « (Secretan, 2002, 233), te ta kršćanska filozofija obuhvaća »svaki razvoj filozofske misli do kojeg se ne bi moglo doći bez izravnog ili posrednog prinosa kršćanske vjere (Secretan, 2002, 233). Kršćanska filozofija »implicira kako, nadilazeći ograničenja 'neovisne' filozofije, razum zadržava svoju filozofsku kvalitetu. Za razum je to stanovito 
obogaćenje, otvaranje prema novim istinama, odnosno dodatak jedne dimenzije mudrosti onomu što je uvijek u opasnosti da se svede na isključivo racionalni tonalitet ljudskoga uma «(Secretan, 2002, 233). A najveći oblik mudrosti je raspeta Božja mudrost, tj. Krist kao logos:

kakav izazov našemu razumu i kakvu korist tek ubire taj razum ako je prihvati! Filozofija, koja je sama po sebi sposobna prepoznati stalnu usmjerenost čovjeka prema istini, može se s pomoću vjere otvoriti da primi 'ludost Križa' kao autentičnu kritiku svih onih koji misle da posjeduju istinu. Odnos između vjere i filozofije u učenju raspetoga i uskrsloga Krista nailazi na stijenu o koju se može razbiti, ali istodobno i stijenu s koje se može otisnuti u beskrajno more istine. Ovdje vidimo ne samo granicu između razuma i vjere nego i prostor u kojem se to dvoje može susresti. (Secretan, 2002, 233).

I Daniel Miščin 2004. godine osvrnuo se je na encikliku u svojem članku u časopisu Scopus naslova 'Fides et ratio' u svjetlu Heideggerove kritike ontoteologije (Miščin, 2004, 7-17). Heidegger naime ne bi prihvatio okružnicu u onom njezinu dijelu gdje je riječ o „naravnoj spoznaji Boga” zbog toga što je ta vrsta spoznaje s onu stranu granice fenomenološke metode primijenjene u njegovoj egzistencijalnoj analizi. Kao što je poznato, Heidegger je pitanje o Bogu ostavio otvorenim, neodlučenim, jer ga u okviru svoje metode smatra neodlučivim. No, zbog toga se Heideggera ipak ne može držati a-teistom, o čemu svjedoče i njegovi posljednji dani života i crkveni ukop!

U časopisu Nova prisutnost 2007. svoj je članak naslova Prirodne znanosti $i$ enciklika Fides et ratio objavio fizičar Marijan Šunjić, nekadašnji rektor Sveučilišta u Zagrebu i diplomat. On ističe kako je čitajući encikliku »otkrio začuđujuću srodnost izloženih ideja sa svojim praktičnim iskustvom znanstvenika, te sustavan okvir za to iskustvo« (Šunjić, 2007, 65). Već je time potvrdio ono što je enciklika i inače isticala, a to je komplementarnost, a ne isključivost razuma i vjere. Što je međutim autor konačno želio polučiti svojim člankom?

Posebno sam želio naglasiti da postoji komplementarnost vjere i razuma, vjerske i razumske spoznaje svijeta, pa prema tome i potreba dijaloga i međusobnog upoznavanja karakteristika tih dvaju načina spoznaje. U vrlo sažetoj analizi znanstvenog procesa sa stajališta samog znanstvenika pokušao sam argumentirati: da postoji granica dosega racionalne spoznaje, posebno znanstvenih istraživanja; da i u znanosti postoji potreba za elementima vjere, koja proizlazi iz naravi i rezultata znanstvenog rada, ali i iz naravi znanstvenika kao ljudskog bića, te da se treba informirano suprotstaviti svim fundamentalističkim, tj. ekstremnim pristupima kao što su scijentizam i fideizam (tj. znanstveni i religiozni fundamentalizam), ali i nihilizam i (etički) relativizam. Analiza enciklike pape Ivana Pavla II. 'Vjera i razum' potvrđuje veliku sukladnost s gore iznesenim zaključcima, kao i s ostalim razmatranjima odnosa znanosti i religije iznesenim u članku, odnosno sukladnost njegovih, kao i službenih stajališta Katoličke crkve, s iskustvenim rezultatima moderne znanosti i brojnih znanstvenika, uključujući i autora. (Šunjić, 2007, 84)

Časopis Diacovensia Katoličkoga bogoslovnoga fakulteta u Đakovu Sveučilišta Josipa Jurja Strossmayera u Osijeku osnovan je istom 1993. pa se nije mogao oglasiti povodom samoga izlaska enciklike, ali je nedavno Stjepan Radić u obliku uvodnika naslova $O$ dvadesetoj godišnjici nastanka i aktualnosti enciklike 'Fides et ratio' podsjetio na 20. godišnjicu enciklike iznoseći njezin tenor, tj. da između vje- 
re i razuma ne smije biti antagonizma, nego naprotiv vladati sklad kojim i vjera i razum mogu profitirati (Radić, 2018, 5-8).

Prije kratkoga vremena pojavio se i prilog u međuvremenu preminuloga švicarskoga kardinala Georgesa Cottiera (1932.-2016.), izvrsnoga poznavatelja misli Tome Akvinskoga te velikoga prijatelja dominikanca o. Tome Vereša, naslova $\mathrm{Za}$ uzetost učiteljstva za svetog Tomu u Fides et ratio (Cottier, 2018). U tom prilogu, koji je svojevrsni pregled čitave enciklike, kardinal Cottier govori o tome kako je učiteljstvo često isticalo Tomu Akvinskoga kao autentičan model za sve one koji traže istinu, pri čemu se izričito spominje njegova odvažnost za istinu, sloboda duha te spremnost za krčenje novih putova u filozofiji i u stvaranju univerzalne kulture.

\section{Zaključak}

Zaključno možemo ustvrditi da se u našoj javnosti pojavak enciklike Fides et ratio, premda i na prigodničarski način, ipak dostatno popratio. Učinili su to oni od kojih se to i očekivalo, poglavito crkvena filozofsko-teološka učilišta te njihovi nastavnici filozofije i teologije, pa i dvojica profesora iz inozemstva. Učinili su to i neki naši filozofi koji ne dijele kršćanski svjetonazor, kao i jedan prirodoznanstvenik. Bili su to korektni prikazi čitave okružnice ili pak nekih njezinih dijelova s posebnom problematikom koja se potom željela pobliže osvijetliti.

Svi su autori isticali da je ta enciklika zapravo jedan dokument o istini. Čovjek je biće koje je svojim razumom usmjereno prema istini. Istina dolazi čovjeku u susret i u obliku pitanja o smislu njegova života, na koje filozofija ne može odgovoriti. Svi su autori zamijetili kako je Ivan Pavao II. sasvim otvoreno na to pitanje filozofiji ponudio kao odgovor objavu u osobi Isusa Krista, koja jednostavno zavrjeđuje da se u nju ima povjerenje! Osim toga, pisci su uočavali u enciklici isticanje nužnoga sklada, odnosno suzvučja između razuma i vjere, a uočili su također i veliku važnost, na Justinovu i Augustinovu tragu, solidnoga studija filozofije koji okružnica traži za teološki kurikulum. Filozofija ne daje teologiji samo znanstveni karakter, nego ima i važnu kerigmatičnu, tj. navjestiteljsku ulogu. Filozofija naime pod tim vidikom može pripomoći identificirati kod čovjeka one njegove „antene” koje mogu „osjetiti” Božju ponudu, i za koju potom taj čovjek kao Hörer des Wortes postaje uvjeren da ga se ona bezuvjetno tiče! Filozofija je osim toga jedino pogodno sredstvo u razgovoru s onima s kojima kršćani ne dijele isti svjetonazor. Valja ustvrditi da upravo na tom području shvaćanja nezaobilaznoga značenje filozofije za teologiju na ovim našim prostorima ima još veoma mnogo prostora za napredovanje!

I napokon, ako se samo pogleda nihilizam koji proviruje iz svih zakutaka te se širi na svim stranama javnoga života, onda se zaista ne može prenaglasiti značenje filozofije, koja ga je, uz teologiju, jedina kadra dokrajčiti, kako je to napisao profesor Despot! Pod tim vidikom ta je enciklika i svojevrsni pledoaje za više filozofije u našem obrazovnom sustavu, kako srednjoškolskom, tako i visokoškolskom. De philosophia numquam satis! 


\section{Literatura:}

Ančić, Nediljko Ante (2008). Neka promišljanja o enciklici Fides et ratio prigodiom desete obljetnice. Bogoslovska smotra, 78(4), 747-760.

Brajičić, Rudolf (2000). Proširenje filozofije na područje Objave. Obnovljeni Život, (55)1, 101-105.

Cottier, Georges (2018). Zauzetost učiteljstva za svetog Tomu u Fides et ratio. U: Anto Gavrić i Marina Novina (ur.), Aktualnost srednjovjekovne filozofije: Tomo Vereš kao inspiracija: Zbornik radova (str. 61-78). Zagreb: Filozofsko-teološki institut Družbe Isusove.

Dadić, Borislav (2000). Metafizika u enciklici Fides et ratio. Obnovljeni Život, (55)3, 389-397.

Despot, Branko (2008). Vjera i filozofija (s ovu i onu stranu uma). Bogoslovska smotra, 78(4), 741-746.

Devčić, Ivan (2000). "Veritatis splendor" i "Fides et ratio" — dva krila jednog triptiha. Obnovljeni Život, 55(1), 91-100.

Eternal Word Television Network (s. a.). Reflections on the Holy Father's Enycyclical Fides et Ratio. URL: https://www.ewtn.com/library/theology/fides.htm (28.10.2018.)

Fisichela, Rino (1998). Introduzione. U: Lettera Enciclica di S. S. Papa Giovanni Paolo II Fides et ratio: I rapporti tra fede e ragione (str. 9-43). Casale Monferrato: Edizioni Piemme.

Hünermann, Peter (2008). Fides et ratio nekoć i sad(?!). Bogoslovska smotra, 78(4), 721-740.

Ivančić, Tomislav (2008), Fides et ratio nakon deset godina. Bogoslovska smotra, 78(4), 761-767.

Jozić, Tomislav (1999). Okolnosti i sadržaj enciklike Fides et ratio. Vrhbosnensia, (3)2, 297-300.

Macan, Ivan (1999). Što nam poručuje enciklika Fides et ratio? Obnovljeni Život, 54(1), 93-110.

Macan, Ivan (2000). Filozofija u crkvenim dokumentima. Obnovljeni Život, 55(1), 25-37.

Markešić, Luka (1999). Današnje zadaće teologije prema enciklici Fides et ratio. Vrhbosnensia, (3)2, 338-346.

Mateljan, Ante (1998a). Za razumnu vjeru i vjerni razum. Crkva u svijetu, 33(4), 323-325.

Mateljan, Ante (1998b). Vjera i razum. Crkva u svijetu, 33(4), 416-423.

Miščin, Daniel (2004). "Fides et ratio" u svjetlu Heideggerove kritike ontoteologije. Scopus: časopis studenata filozofije Hrvatskih studija, 20, 7-17.

Mišić, Anto (2000). Otački vidici odnosa “vjere i razuma”. Obnovljeni Život, 55(1), 53-60.

Pavić, Željko (1999). Bog Abrahamov i Bog filozofa: Filozofijski dometi enciklike Fides et ratio. Vrhbosnensia, (3)2, 317-337.

Platz, Slavko (2000). Uloga i odnos vjere i uma u ruskoj religijskoj filozofiji. Obnovljeni Život, 55(1), 81-90.

Radić, Stjepan (2018). O dvadesetoj godišnjici nastanka i aktualnosti enciklike "Fides et ratio". Diacovensia 26(1) 5-8.

Radman, Vili (1999). Potraga za istinom kao antropološka pretpostavka kršćanske vjere. Vrhbosnensia, (3)2, 306-312.

Ring-Eifel, Ludwig (2018). Eine denkwürdige Enzyklika - nicht nur für Philosophen. U: Katolich.de. URL: http://www.katholisch.de/aktuelles/aktuelle-artikel/einedenkwurdige-enzyklika-nicht-nur-fur-philosophen (15.09.2018.)

Scheffczyk, Leo (1999). Theologisches Plädoyer für die Vernunft. Zur Enzyklika Fides et Ratio Johannes Paulus II. Forum Katholische Theologie, 1, 48-59. 
Secretan, Philibert (2002). Kršćanska filozofija prema Aeterni patris i Fides et ratio. U: Anto Mišić (ur.), Oči vjere: Zbornik u čast Josipa Ćurića SJ u povodu 75. obljetnice Života (str. 229-235). Zagreb: Filozofsko-teološki institut Družbe Isusove.

Skledar, Nikola (1999). Vjera i razum. Zaprešićki godišnjak, 8, 299-313.

Stanković, Nikola (2000). "Fides et ratio" — konsekvencije za filozofiju o Bogu. Obnovljeni Život, 55(1), 61-70.

Šestak, Ivan (2000). Riječ urednika. Obnovljeni Život, 55(1), 3-5.

Šunjić, Marijan (2007). Prirodne znanosti i enciklika Fides et ratio. Nova prisutnost, 5(1), $65-85$.

Tadić, Ivan (2000). Razum i spoznaja u enciklici Fides et ratio. Obnovljeni Život, (55)3, $39-51$.

Zelić, Ivan (2000). Toma Akvinski u Enciklici Fides et ratio. Obnovljeni Život, 55(1), 71-80. Zenko, Franjo (2014). Razum i vjera. Bogoslovska smtora, 84(2), 235-243.

Zovkić, Mato (1999). Riječ Božja u enciklici Fides et ratio. Vrhbosnensia, (3)2, 301-305.

\section{The Reception of the Encyclical Fides et Ratio by Croats}

Ivan Šestak*

\section{Summary}

This article highlights the presence in Croatia of John Paul II's encyclical Fides et Ratio on the occasion of the twentieth anniversary of its publication. Hence, the article gives a chronological list of reviews on the encyclical in Croatian scientific periodicals, which are generally associated with philosophical-theological institutions in Croatia. Articles were published in the journals Crkva u svijetu (The Church in the World), Obnovljeni život (Renewed Life) and Bogoslovska smotra (The Seminarian Review) and in other places also, though the latter are almost negligible. Writings were occasional in nature, i.e., they were issued at the time of the publication of the encyclical and on the marking of its anniversaries. The aforesaid are very good presentations of the entire document or of individual sections on whatever problem the authors deal with in their scholarly endeavours. Following the encyclical, they wrote about the meaningful relationship between reason and faith throughout history, or rather philosophy and theology as the sciences of faith, of the openness, in principle, of the human spirit to the truth which is of a transcendent nature, of the necessity of philosophy for theology, of the natural sciences and the encyclical, of the abomination of nihilism which is a true negation of humanity, and of the offer of Jesus Christ's message which John Paul II proposed to philosophy. It must be mentioned also that certain authors tended to make critical references to some sections of the encyclical.

Key words: Fides et ratio, faith, reason, philosophy, theology

* Ivan Šestak, Ph.D., Associate Professor. Faculty of Philosophy and Religious Studies, University of Zagreb. Address: Jordanovac 110, 10000 Zagreb.E-mail: isestak@ffrz.hr 